\title{
Vibration Diagnostics of Marine Diesel Engines Malfunctions Connected with Injection Pumps Supported by Modelling
}

\section{Vibracijska dijagnostika kvarova na brodskim dizelskim motorima, povezanih s pumpama za ubrizgavanje goriva, uz modeliranje}

\author{
Marcin Kluczyk \\ Polish Naval Academy, Mechanical- \\ Electrical Department \\ Gdynia, Poland \\ E-mail:m.kluczyk@amw.gdynia.pl
}

\section{Summary}

The article presents main causes of malfunctions in marine diesel engines fuel injection systems. The measurement section focuses on damage to injection pumps. Measurements were carried out for three technical conditions of a given cylinder injection pump. At the same time, a simplified vibration model of the engine was presented allowing to indicate sensitive components in the frequency domain enabling identification of damages to injection pumps working with individual cylinders. Finally, the results obtained by modelling were compared with the results recorded during laboratory measurements.

\section{Sažetak}

U radu izlažu se glavni uzroci kvarova na sustavima ubrizgavanja goriva brodskih dizelskih motora. Dio koji se bavi mjerenjima usredotočava se na oštećenja na pumpama za ubrizgavanje. Mjerenja su se uzimala tijekom triju različitih tehničkih uvjeta rada određene pumpe cilindra. Istovremeno, prikazuje se pojednostavnjen vibracijski model motora kako bi se moglo usmjeriti na osjetljive sastavnice u odnosu na frekvencije te da bi se omogućilo utvrđivanje oštećenja na pumpama za ubrizgavanje koje opslužuju pojedinačne cilindre. Na kraju, rezultati dobiveni modeliranjem uspoređeni su s onima dobivenima laboratorijskim mjerenjima.
DOI $10.17818 / \mathrm{NM} / 2020 / 3.4$

UDK 621.436:629.5

Original scientific paper / Izvorni znanstveni rad Paper accepted / Rukopis primljen: 22. 4. 2020.

\section{KEY WORDS}

marine engines

vibrations

diagnostic

\section{INTRODUCTION / Uvod}

As far as marine equipment strategy of operation is based on their current technical condition, a set of reliable diagnostic methods should be available. They are used for clear defining technical condition of all components important from the point of view of reliability. One of such methods is vibration diagnostics. Use of vibration measurements in diagnostic systems allow to determine the optimal moment of shutting down the machine in order to perform necessary repairs. The moment of defect occurrence and its propagation, up to the catastrophic damage, could be illustrated as on figure 1 .

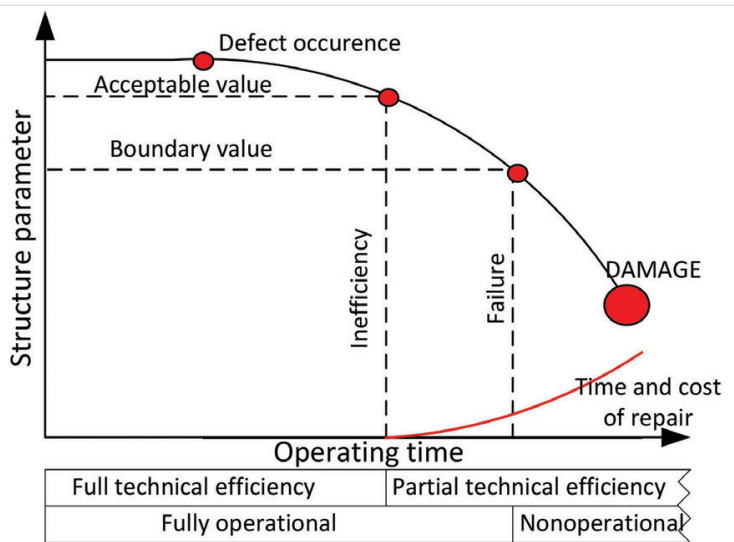

Figure 1 Marine diesel engine possible life chart

Slika 1. Mogući vijek trajanja brodskog dizelskog motora
It should be assumed that the moment of defect appearance do not eliminate the engine from further operation. However personnel have to be aware of the situation and have tools enabling observation of defect development. The main purpose of the marine diesel engine injection system is to provide appropriate fuel doses with correct atomization of fuel in the cylinder at a certain angle before TDP. Each of the mentioned parameters describing the operation of the injection system is characterized by certain limits given by the engine producer. As long as these values do not exceed the permissible (limit) values, the engine is in a full technical efficiency condition. After exceeding the limits, the condition is being changed to a state of partial technical efficiency. However, it can still be operated. It is important that the technical staff is aware of the need to quickly repair of developing defect. If an existing defect is not detected at this stage, it usually develops very quickly leading to engine failure.

All working machines, also those in good technical condition, are a source of vibrations as a form of dissipated energy. In the vast majority of cases (but not always, for example, vibrations caused by the flow of the medium), they can be linked to periodic phenomena occurring in the machine, e.g., a rotating shaft, gear teeth or frequency of supply voltage in electric machines. Usually, the relationship between values and magnitude and/or phase of their occurrence is relatively simple do determine. From the point of view of vibration diagnostic it 
is useful and serves to fast assess the technical condition of the tested device.

Taking into consideration many years of experience gathered at the Institute of Construction and Operation of Warships, an analysis of the occurrence of operational incapacity of marine engines operated in Polish navy was carried out - Figure 2. The conducted analysis presented that the most common defects occur in the following functional systems [6]:

engine fuel supply system - $72 \%$,

timing system - $19 \%$,

engine power supply system - $9 \%$.

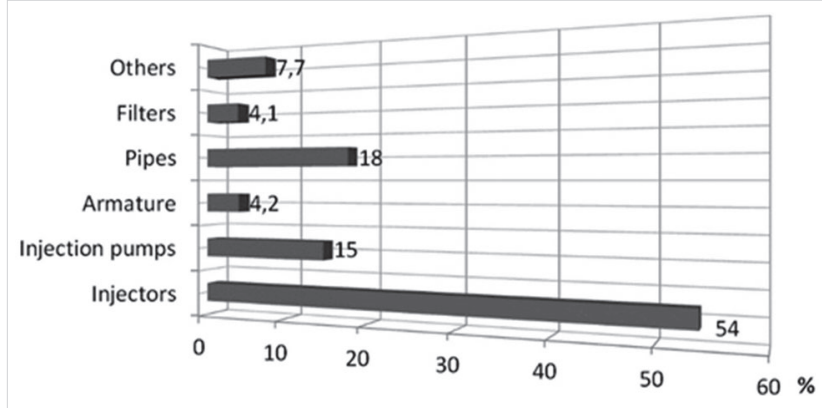

Figure 2 Percentage contribution of failures to individual elements of the fuel installation [6]

Slika 2. Postotak udjela u kvarovima pojedinih elemenata instalacije goriva [6]

From the diagnostic point of view, exceeding the permissible values connected with the operation of fuel systems of marine diesel engines has two main consequences:

- leads to changes in mean effective pressure (Fig. 3),

- changes in pressure distribution as a function of crankshaft angle (CA).

The paper is focused on the subject of injection pumps vibration diagnostics because although their failures do not constitute the biggest percentage their identification can be considered as the most difficult. On small vessels (particularly naval vessels), there are no portable stands for testing injection pumps, unlike stands for injector testing.
Changes in the technical condition of the fuel system could cause a decrease in the quality of the inside cylinder processes. Additionally, in the long term, could cause serious secondary damage to other components of the naval power unit, such as turbochargers, flexible couplings or torsional dampers. It is the reason why early detection of changes in the technical condition of injection pumps can also prevent secondary failure to other components of the propulsion system. Currently, one of the best methods to accurately indicate the reason of disturbances in inside cylinder pressure is the indication procedure. In many cases, it cannot be made due to the lack or failure of indicator valves. The analysis of the literature gives the information that issues related to the vibration diagnostics of diesel propulsion engines, have not found a clear and acceptable methodology. Despite the inability to indicate, it is advisable for the personnel to have diagnostic information from other sources $[7,8,11$, 12]. In view of the above, an important issue is the selection of measurement and analysis optimal method of vibration signals. It allow to determine the technical condition of injection pumps of the marine engines.

\section{THE COURSE OF RESEARCH / Tijek istraživanja}

Gas pressure pulsation in the cylinder will result in a change of force affecting its crank-piston mechanism and the surfaces closing the combustion chamber $[3,4,10]$. Therefore, it can be assumed that the vibration parameters recorded in the immediate vicinity of the cylinder operating with the faulty injection system will differ from the reference one [4]. At the initial stage of the study to determine the diagnostic sensitivity, the comparison of the amplitude spectra of the vibration accelerations obtained from measurements carried out at various points of the engine was made. On this basis, two measuring points located in two mutually perpendicular directions $\mathrm{V}$ (vertical) and $\mathrm{H}$ (horizontal) have been selected as the most susceptible to changes in the indicated pressure Fig. 4. The substantiation is, the distribution of the main forces occurring in the crank-piston mechanism of the working diesel engine, what is presented. After performing the analysis of the suitability of the recorded vibration parameters, a further part

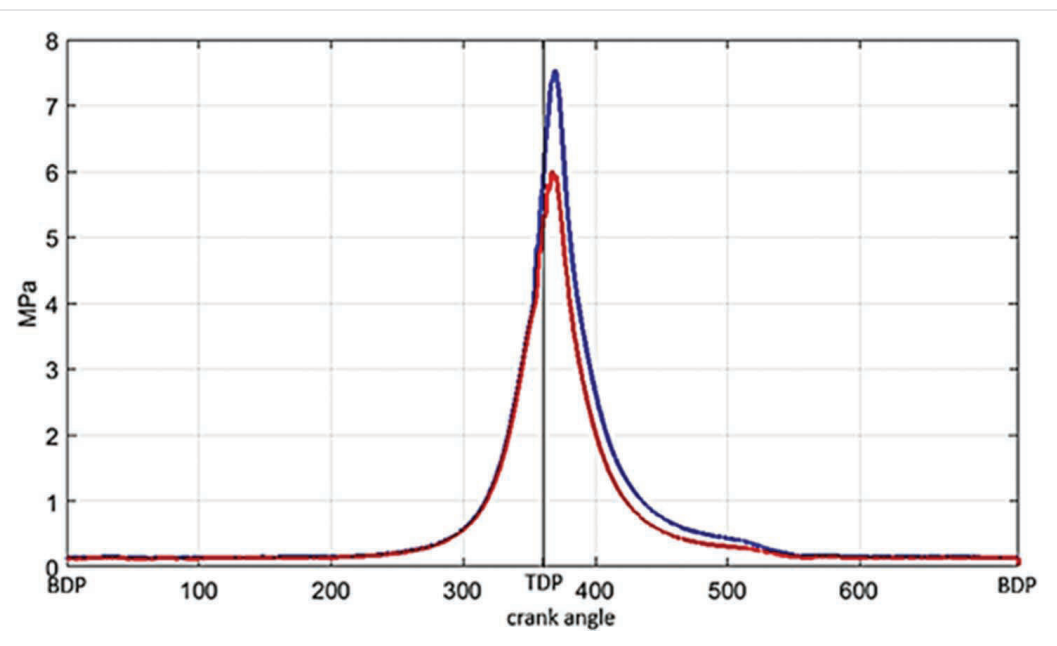

Figure 3 An example of the course of pressure changes in the cylinder of the Sulzer AL 20/24 engine working with efficient (blue line) and damaged injection pump (red line)

Slika 3. Primjer izmjena u promjenama tlaka u cilindru Sulzer AL 20/24 motora koji radi s ispravnom (plava crta) i oštećenom pumpom goriva (crvena crta) 

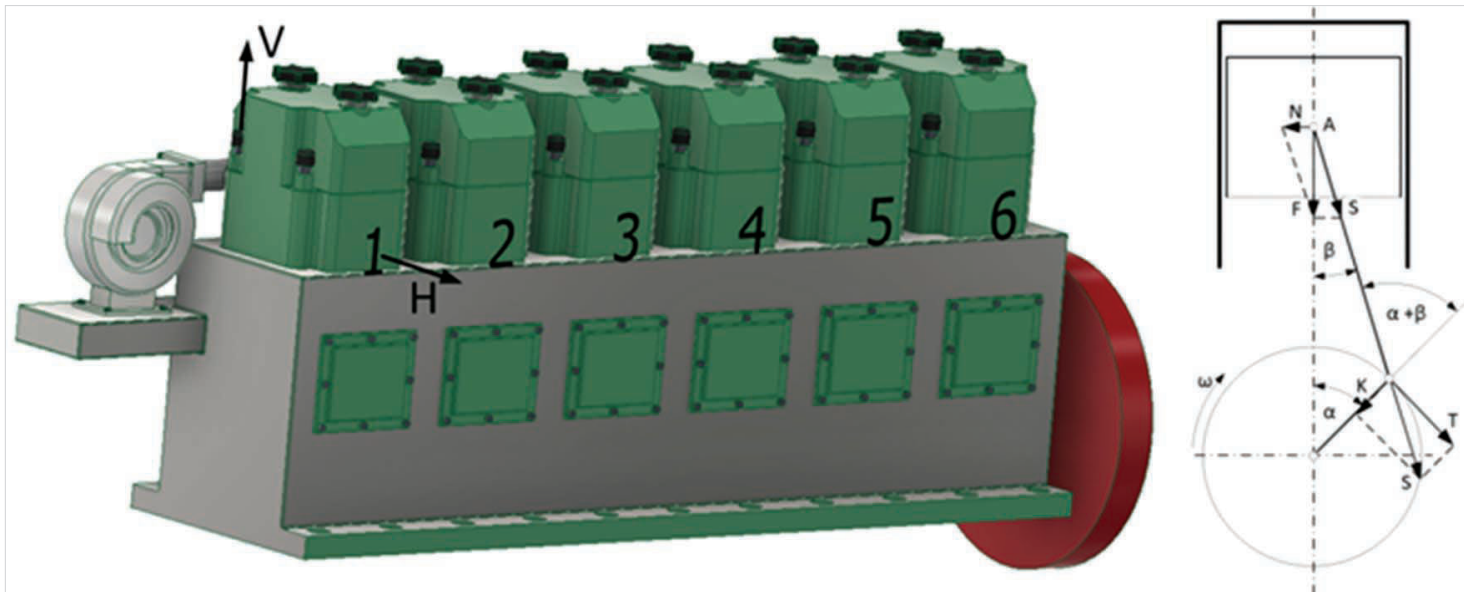

Figure 4 A simplified model of the 6 AL 20/24 engine with measurement axes (V, H) and force distribution in the crank-piston mechanism

Slika 4. Pojednostavnjen model 6 AL 20/24 motora s mjernim osima $(V, H)$ i raspodjela snage u klipnom mehanizmu

of the tests was conducted only in relation to the vibrations recorded in the measuring axis $\mathrm{V}$.

During all stages of the research, vibration parameters were measured on subsequent heads of individual cylinders. Measuring points in the direction $\mathrm{V}$ (fig 5) were located on the tightening bolts of individual cylinder heads. Signals of accelerations were measured which were filtered by high pass filter with cot of frequency of $0,7 \mathrm{~Hz}$. Subsequently FFT procedure was used.

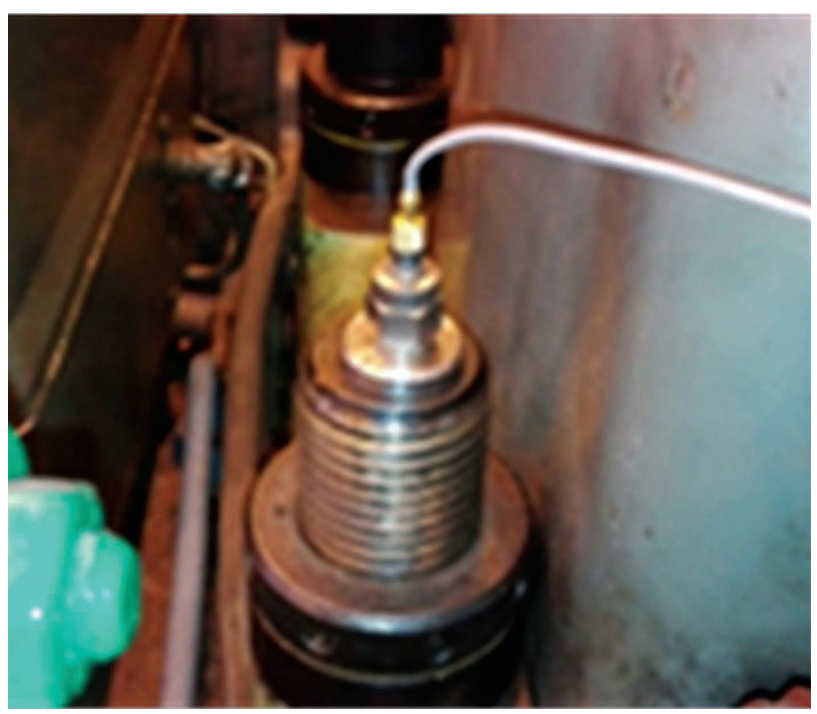

Figure 5 An example of accelerometer assembly on the Sulzer tightening bolt - direction $\mathrm{V}$

Slika 5. Primjer sklopa akcelerometra na Sulzer priteznom vijkupravac $V$

The measurements were carried out in three stages corresponding to various technical states of the injection pump. The simulation of a change in the technical condition of the injection pump was gained by changing the pressure in the injector supply pipe. This change was obtained by adjusting the overflow screw on the pump discharge side. In order to determine the effect of the position of the overflow screw on the amount of fuel injected into the combustion chamber, cylinder pressure was continuously indicated (Fig. 3). During the first stage of the tests, vibration parameters of all cylinders were measured in a state of full technical efficiency, the results obtained during this stage served as reference. The next step was to take measurements with the injection pumps of individual cylinders switched off, which resulted in the simulation of the misfiring. During the last phase, the measurements were carried out for partial condition of individual injection pumps. The amount of fuel was reduced to the level at which the indicated pressure reduction was obtained by about $20 \%$ compared to the operation of a cylinder with a efficient injection pump. All stages of the tests were carried out in similar atmospheric conditions and for the same engine torque loads.

\section{MARINE DIESEL ENGINE VIBRATION SIMULATION MODEL / Simulacijski model vibracija brodskog dizelskog motora}

At the same time, a simplified model of dynamics was developed in Matlab. The main source of vibration excitations in working engine is rapid pressure changes occurring during the working stroke $[1,2,10]$. Therefore, when designing the model it was necessary to mathematically describe the course of pressure changes in individual engine strokes. Analyse of literature gives us information about many different diesel engine pressure models, but usually, they are difficult to implement in the final engine vibration model $[3,7,8,10]$. In order to create a simplified pressure model according to the Sabathe theoretical cycle, it is necessary to determine the characteristic parameters of the engine cycle [2,5]: - boost pressure, - exhaust pressure, $\varepsilon$ compression ratio, - compression polytrope exponential index, - expansion polytrope exponential index, - pressure increase ratio, $\rho$ - volume increase ratio, $r$ - crank radius, $\lambda$ - crank radius to the connecting rod length ratio, $D$ - cylinder diameter, $\omega$ crankshaft angular velocity.

To create a model, it was assumed that in the intake stroke (in the range from 0 to $180^{\circ} \mathrm{CA}$ ) the gas force acting on the piston remains constant and takes the value specified by the formula (1) [2]:

$$
F_{g}=\frac{\pi D^{2}}{4}\left(p_{d}-p_{0}\right)
$$

where: $p_{0}$ - ambient air pressure.

In the next, compression stroke ( 180 to $360^{\circ} \mathrm{CA}$ ), the change in gaseous force might be described by the equation

$$
F_{g}=\frac{\pi D^{2}}{4}\left\{p_{d}\left[\frac{2 \varepsilon}{(\varepsilon-1)\left(1-\cos \varphi+0,5 \lambda \sin ^{2} \varphi\right)+2}\right]^{n_{1}}\right\}
$$


In the work stroke (from 360 to 540 o CA), the value of gas force will change approximately according to the dependence:

$$
F_{g}=\frac{\pi D^{2}}{4}\left\{p_{d} \varphi_{c} \varepsilon^{n_{1}}\left[\frac{2 \rho}{(\varepsilon-1)\left(1-\cos \varphi+0,5 \lambda \sin ^{2} \varphi\right)+2}\right]^{n_{2}}\right\} \text { (3) }
$$

The approximate value of the gas force in the exhaust stroke ( 540 to 720 o CA) can be considered as constant and described by the equation:

$$
F_{g}=\frac{\pi D^{2}}{4}\left(p_{w}-p_{0}\right)
$$

In diesel engines, the initial phase of the expansion stroke is an isobaric increase in volume and in this phase the formula (3) might not be applied. According to the literature [2] this formula can be used. The condition is to replace the gaseous forces greater than those induced by the theoretical maximum pressure $p$ with the forces corresponding to this pressure. The maximum pressure is expressed by:

$$
p_{z}=p_{d} \varphi \varepsilon^{n_{1}}
$$

In contrast, the gas forces caused by this pressure are described by the equation:

$$
F_{g}=\frac{\pi D^{2}}{4}\left(p_{z}\right)
$$

The substitution should occur in the range from 360 to oCA, where is given by the equation:

$$
\varphi_{k}=\arccos \frac{\sqrt{1+2 \lambda\left(1+0,5 \lambda-2 \frac{\rho-1}{\varepsilon-1}\right.}}{\lambda}
$$

As a result of the implementation of the presented equations and basic dimensions and masses of the Sulzer 6AL 20/24 engine to the MatLab script, the course of cylinder pressure changes shown in Figure 6 was obtained.

Such a chart of pressure is unusable for further create a diesel engine vibration model due to step changes in pressure at the ends of each stroke. Therefore, the authors used one of the nonparametric methods of regression, i.e. weighted localpolynomial regression (loess - locally weighted scatterplot smoothing). As a result of applying the loess function to the course presented in Figure 6, a course much closer to the recorded during the engine's indication was obtained. The comparison of the three real curves obtained from the model and obtained from the model using the loess function was shown in Figure 7.

In order to determine the conformity of the cylinder pressure course obtained by modelling with the course recorded during the engine's indication in the first stage, the Pearson's linear correlation function was used (the dimensions of both matrices are identical). The correlation coefficient of two variables describes their linear dependence taking values from -1 to 1 . If both variables are $\mathrm{N}$-length then the Pearson's linear correlation coefficients take the form:

$$
r_{A B}=\frac{1}{N-1} \sum_{i=1}^{n} \overline{\left(\frac{A_{l}-\mu_{A}}{\sigma_{A}}\right)\left(\frac{B_{l}-\mu_{B}}{\sigma_{B}}\right)}
$$

Where and are the mean and standard deviation of the set $A$, while and are the mean and standard deviation of the set $B$. The linear correlation coefficient can also be calculated using the covariance function:

$$
r_{A B}=\frac{\operatorname{cov}(A, B)}{\sigma_{A} \sigma_{B}}
$$

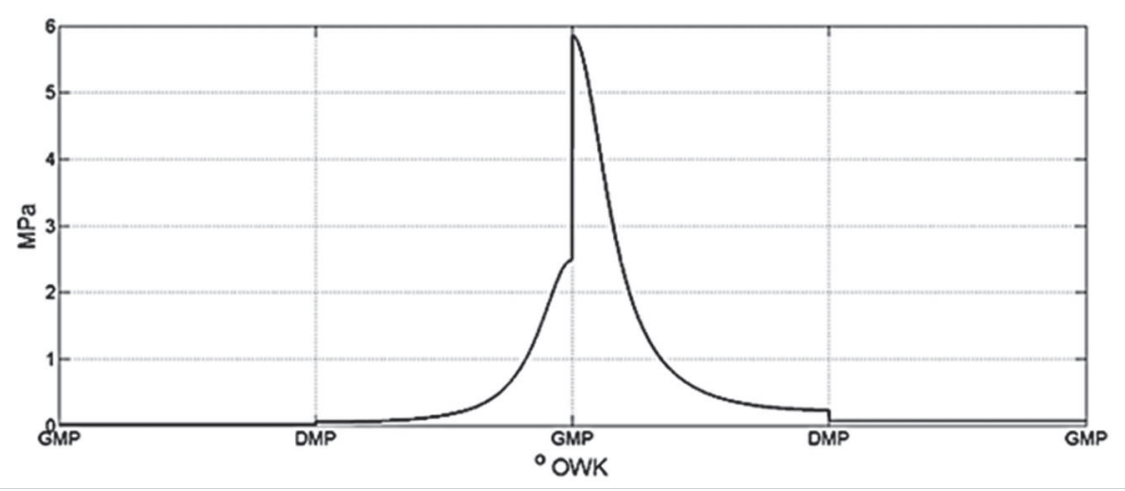

Figure 6 Changes in indicated pressure obtained as a result of modelling Slika 6. Promjene u naznačenom tlaku kao rezultat modeliranja

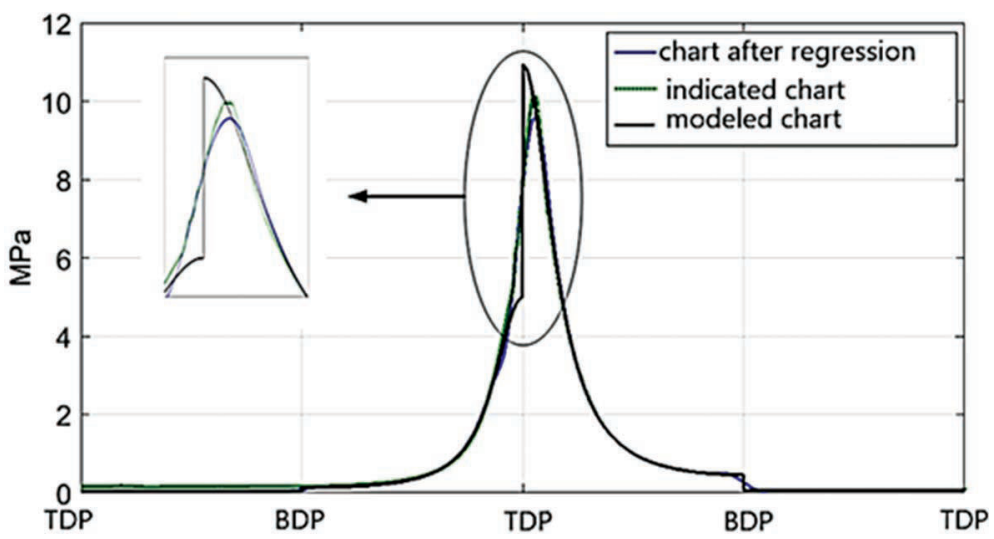

Figure 7 Comparison of the course of pressure changes obtained by three different methods Slika 7. Usporedba kretanja izmjena u tlaku dobivenih s pomoću triju različitih metoda 


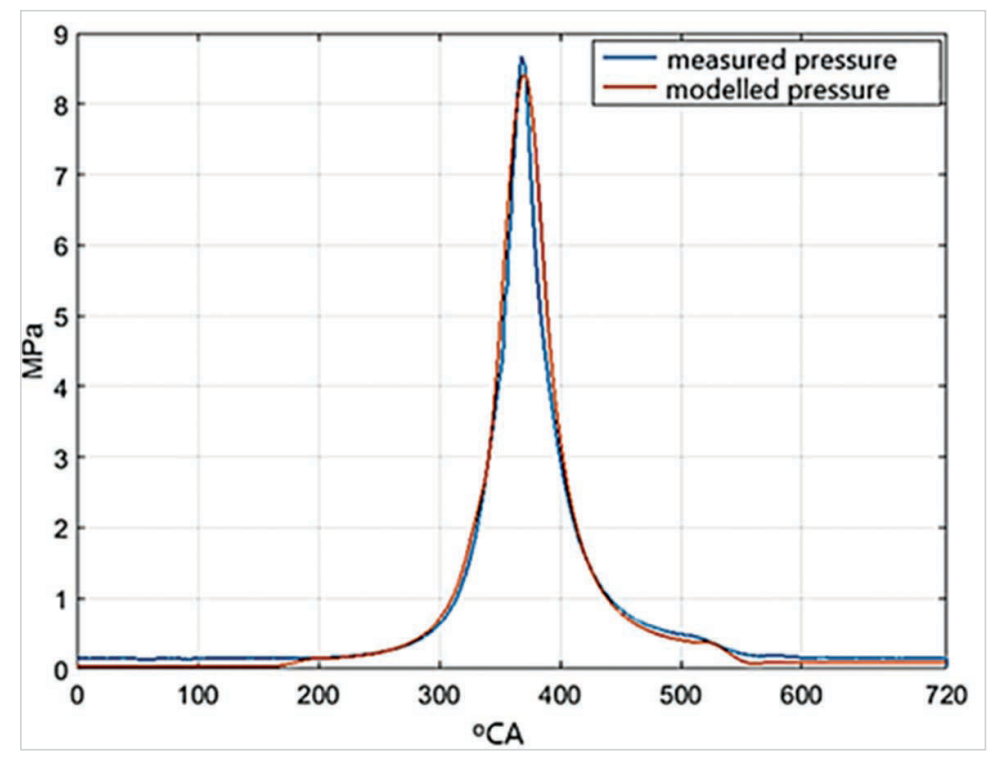

Figure 8 Indicated and modelled cylinder pressure course for an efficient engine operating at $750 \mathrm{rpm}$ with a load of 3,3 kNm Slika 8. Kretanje naznačenog i modeliranog tlaka u cilindru motora koji radi na 750 okretaja i sopterećenjem od 3,3 kNm

After applying the corrcoef function, a correlation matrix with the following form is obtained:

The following values were obtained for the test runs shown on Figure 8:

$$
\left[\begin{array}{cc}
1 & 0,952 \\
0,952 & 1
\end{array}\right]
$$

The obtained results confirm a very strong linear relationship between the indicated pressure course recorded during test stands and the course obtained from the simulation model.

Main source of vibrations in marine diesel engine are forces connected with pressure caused by fuel explosions. The values of the maximum combustion pressures differ from cylinder to cylinder even an fully efficient engine. There are a lot of factors affecting the diversity of the combustion processing in individual cylinders. The most important are different injection crank angles, different doses of injected fuel resulting from different pressures of individual injection pumps, different opening pressures of the injectors and, finally, different efficiency of fresh charge exchange in cylinders. All these factors result in different pressure courses in individual cylinders as it is presented on figure 9.

Developing engine dynamics model, the firing order was taken into account as well as the distribution of forces in the crank-piston mechanism, also the forces related to the operation of suspended mechanisms were included. The implementation of the obtained pressure model for the engine dynamics simulation model allowed to generate modelled time courses of vibration accelerations for various engine operating states. The comparison of the model chart (in relation to the efficient engine) and the chart recorded on engine's cylinder no. 1 is shown in Figure 10 and 11.

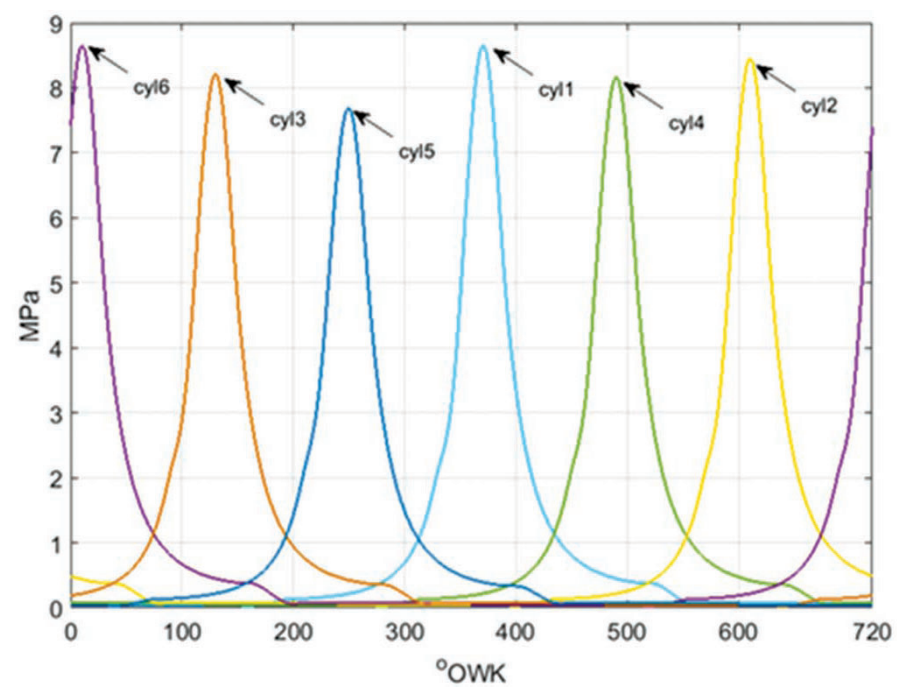

Figure 9 Cylinders pressure waveforms of fully technical efficient engine obtained by modelling Slika 9. Valovi tlakova cilindara tehnički potpuno učinkovitog motora, dobiveni modeliranjem 


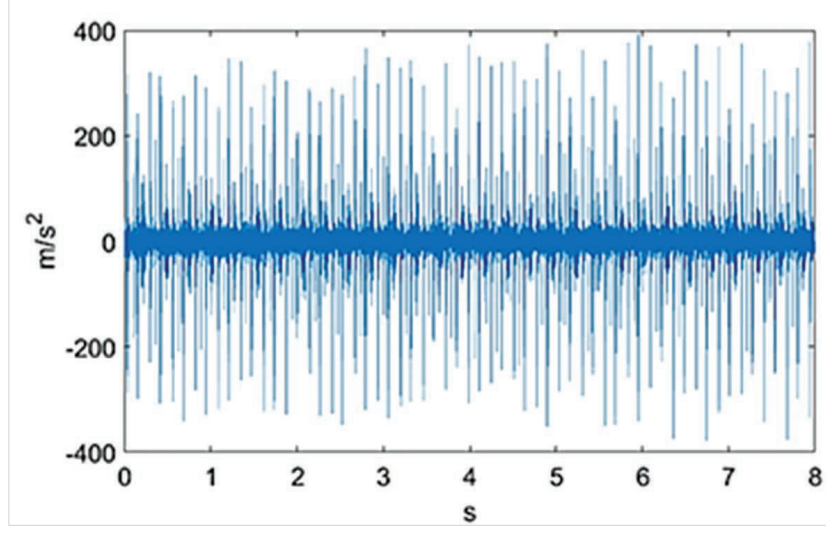

Figure 10 Vibration accelerations obtained during measurements on the real object

Slika 10. Ubrzanja vibracija dobivena mjerenjem na stvarnom objektu

\section{RESULTS / Rezultati}

During the tests, the fuel supply to individual cylinders was not completely cut off, only the parameters of fuel injection into the combustion chamber were changed. The comparison of Figures $12 \mathrm{a}$ and $12 \mathrm{~b}$ leads to the conclusion that in the case of mediumspeed marine diesel engines the reduction of combustion pressure value in the cylinder without its complete shutdown is almost unobservable. Figures $12 \mathrm{a}-12 \mathrm{c}$ present the time series of vibration accelerations recorded during the operation of the Sulzer 6 AL 20/24 engine at a speed of $500 \mathrm{rpm}$ and a load of $1.3 \mathrm{kNm}$. The following figures show the accelerations recorded on the cylinder head of a fully efficient engine (12a), with a fuel dose reduced by about $20 \%$ (12b), and with the injection pump turned off completely (12c). Turning off the injection pump

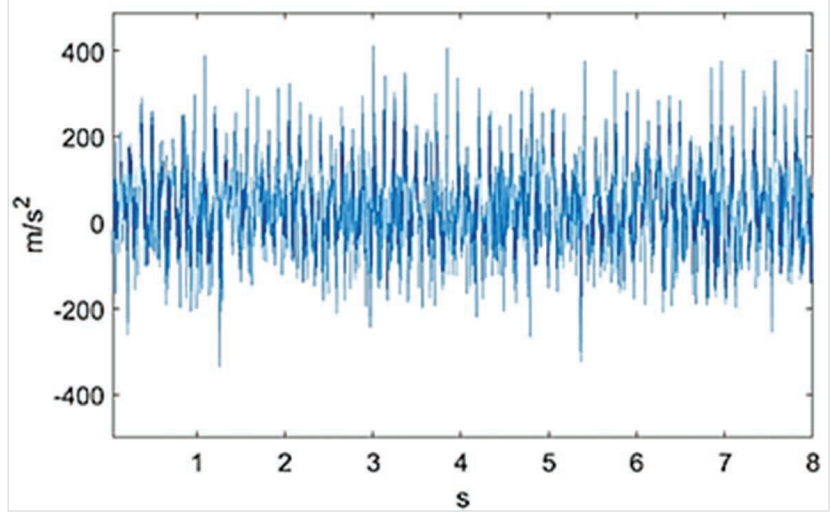

Figure 11 Vibration accelerations obtained through modelling Slika 11. Ubrzanja vibracija dobivena modeliranjem

simulates the misfire in a cylinder (fuel is not fed to the injector). The reduction of the injection pump discharge pressure simulates the frequent failure of injection pumps, consisting in loss of leakproof of the injection pump piston-cylinder connection. Loss of leakproof occurs during the natural process of wear of these elements, as well as a result of the formation of scratches, which are caused by solid impurities from the fuel.

Using the Fourier's theory, recorded time courses were switched from time to frequency domain. The obtained waveforms were subjected to a comparative analysis for changes in amplitude values that may be related to the technical condition of individual cylinders injection pumps. The reference courses were vibration acceleration waveforms recorded on a test stand during fully technical efficient engine operation.
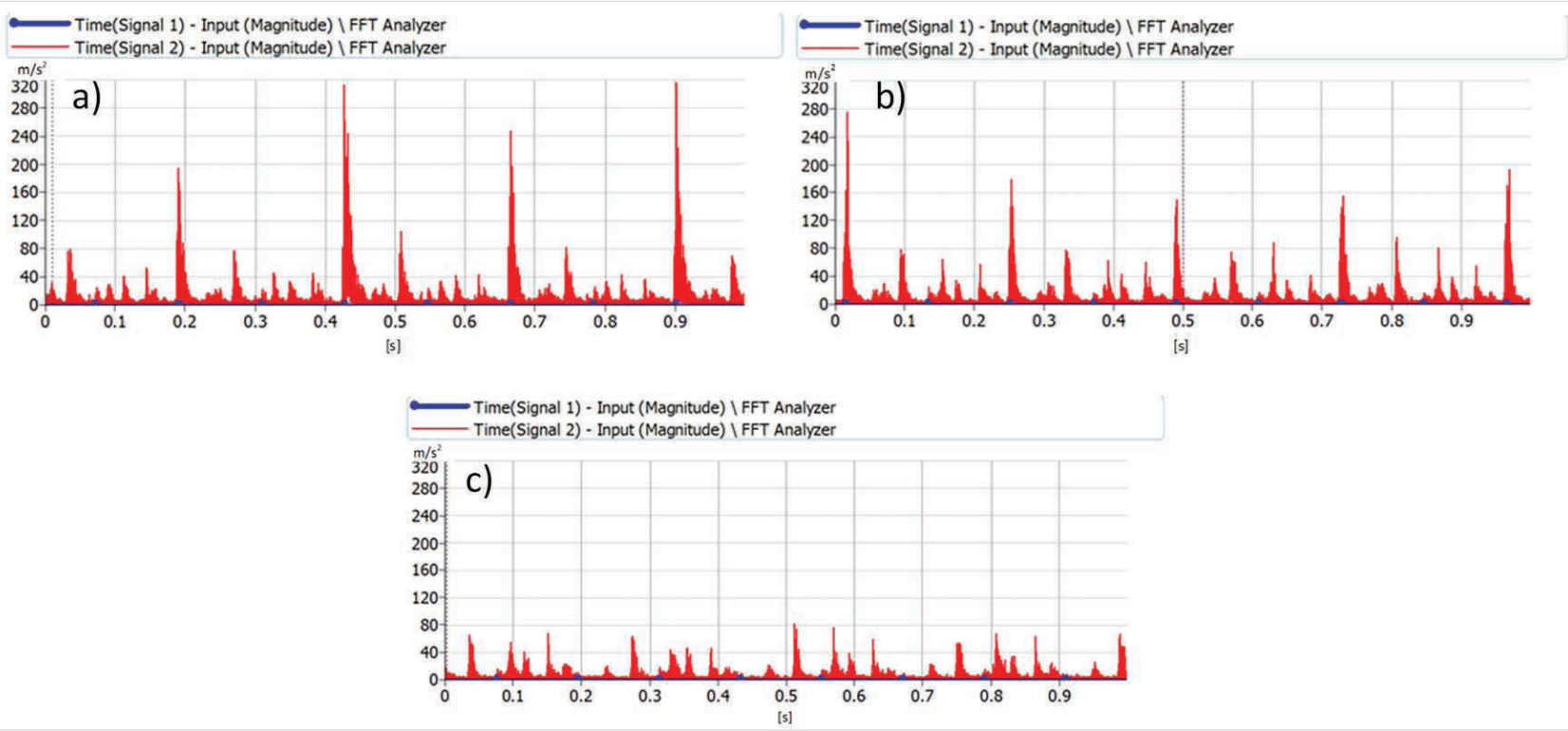

Figure 12 Time courses of vibration accelerations recorded in the $V$ direction on the cylinder head No. 6 during operation of Sulzer 6 AL 20/24 engine at $500 \mathrm{rpm}$ and load of $1.3 \mathrm{kNm}$; a) - nominal injection pressure, b) - injection pressure reduced by about $20 \%$, c) - injection pump of cylinder number 6 turned off

Slika 12. Vremenski tijek ubrzanja vibracija snimljen u V pravcu glave cilindra br. 6 tijekom rada Sulzer 6 AL 20/24 motora na 500 okretaja i pod opterećenjem od 1,3 kNm; a) - nominalni tlak ubrizgavanja, b) - tlak ubrizgavanja smanjen za otprilike 20\%, c) isključena pumpa na cilindru br. 6 


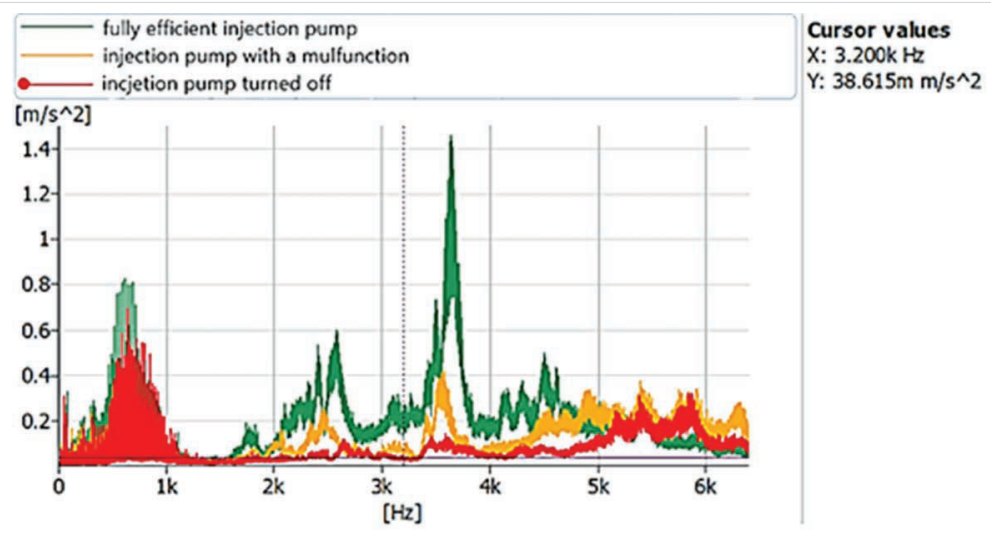

Figure 13 Acceleration vibration amplitude spectra of the SULZER 6AL 20/24 engine cylinder no. 1, recorded in the direction V for a rotational speed of $750 \mathrm{rpm}$ and a load of $3,2 \mathrm{kNm}$

Slika 13. Amplituda ubrzanja vibracija na cilindru br. 1 SULZER 6AL 20/24 motora, snimljena u pravcu V za rotacijsku brzinu od 750 okretaja i opterećenje $3,2 \mathrm{kNm}$

In figure 13, the green colour line indicates the reference spectrum of engine vibration acceleration; orange colour line refers to the engine working with partially efficient injection pump on a cylinder which the accelerometers were mounted. Red spectra were recorded after turning off the injection pump. It is observable that switching off the injection pump caused a significant reduction in the amplitude values in the whole measuring range. Similar results were obtained by switching off the injection pumps of the tested engine remaining cylinders. It allows forming the conclusion that ignition misfires are relatively easily detectable using vibration methods. Which is why in the next part of the work was focused on determining the possibility of detecting the initial stages of the inefficiency of injection pumps. Simulated damage to the injection pump consisting in reducing the amount of fuel injected into the combustion chamber caused

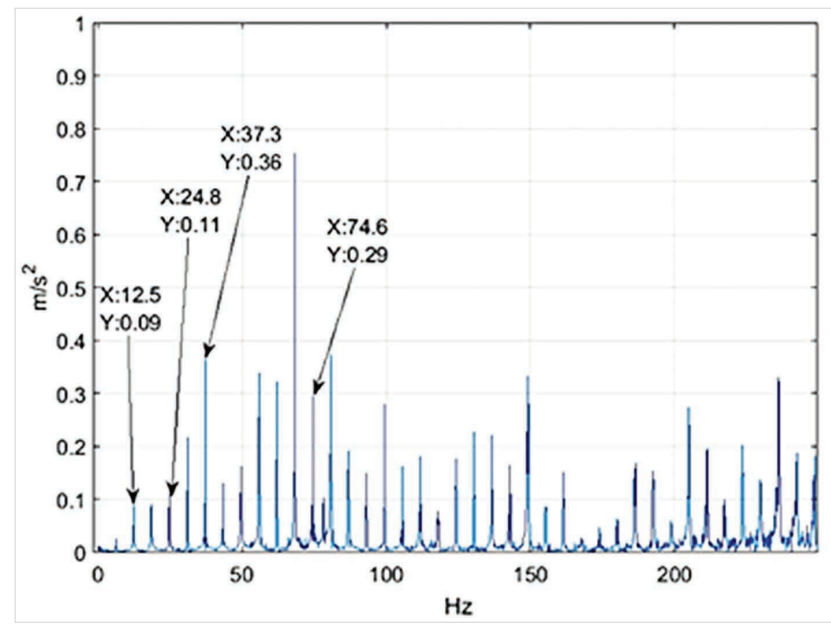

Figure 14 Acceleration vibration spectra of the cylinder no. 1 of the efficient 6 AL 20/24 engine at the rotational speed of 750 rpm for the real object

Slika 14. Spektar ubrzanja vibracija na cilindru br. 1 motora 6 AL 20/24 u radu na 750 okretaja za stvarni objekt a decrease in amplitude in the higher frequency range (above 1,5 $\mathrm{kHz}$ ), however, it is not as clear and repetitive as in the case of misfires. This was the reason for looking at symptoms that could determine the technical condition of the injection pump in the low frequency range. Characteristic frequencies resulting from the principle of operation and construction of the tested engine were selected. They were marked in Figures 14-17 and indicated in Table 1. At the same time, values of amplitudes obtained during measurements and as a result of engine vibration modelling were carried out. Slight differences in frequency values result from the engine governor principle of working. It follows that the actual rotational speed of the engine crankshaft oscillates slightly around the speed set by the user. In the case of results obtained from the model, the frequency values do not differ because a constant rotational speed of $750 \mathrm{rpm}$ was applied.

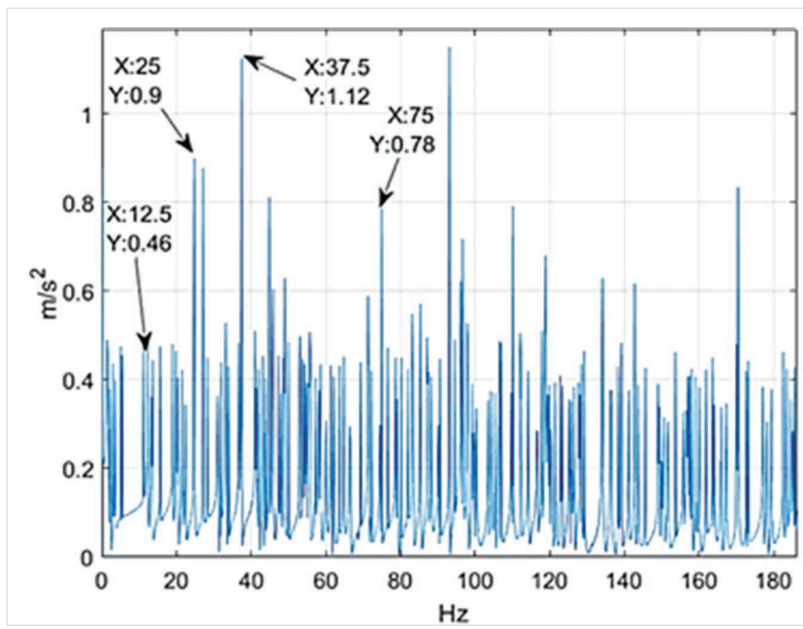

Figure 15 Acceleration vibration spectra of the cylinder no. 1 of the efficient 6 AL 20/24 engine at the rotational speed of 750 rpm obtained as a result of modeling

Slika 15. Spektar ubrzanja vibracija na cilindru br. 1 motora 6 AL 20/24 na 750 okretaja, dobiven kao rezultat modeliranja 


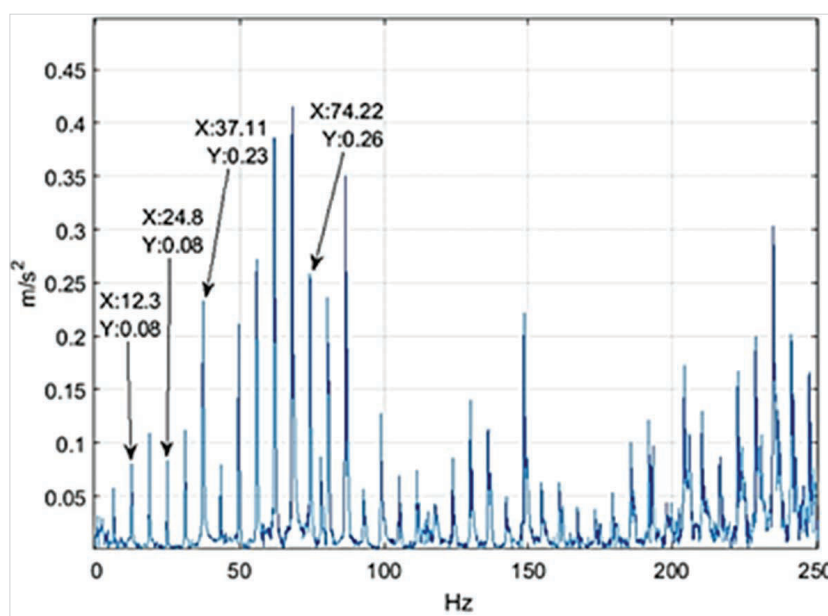

Figure 16 Acceleration vibration spectra of the cylinder no. 1 of the engine 6 AL 20/24 working with the damage of the injection pump cylinder No. 1 for the rotational speed of 750 rpm - real object

Slika 16. Spektar ubrzanja vibracija na cilindru br. 1 motora 6 AL 20/24 koji radi s oštećenjem pumpe za ubrizgavanje na cilindru br. 1 na 750 okretaja - stvarni objekt

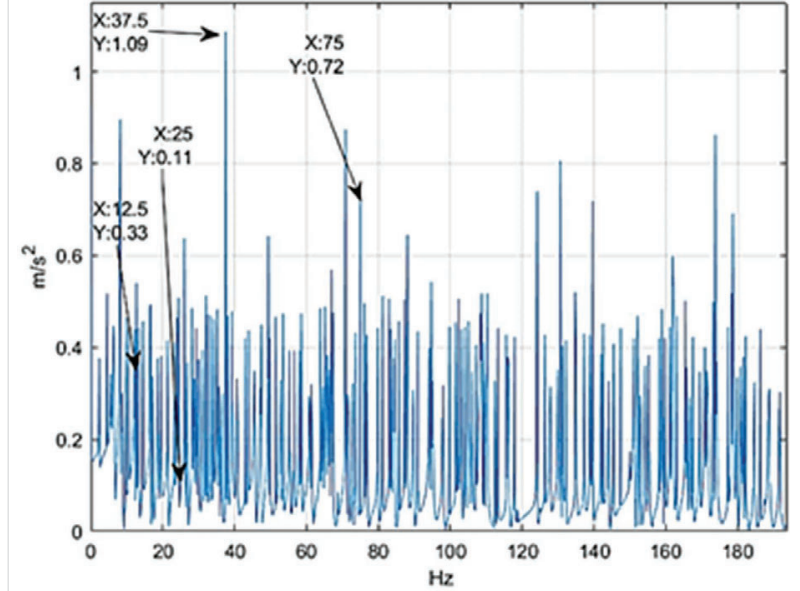

Figure 17 Acceleration vibration spectra of the cylinder no. 1 of the engine 6 AL 20/24 working with the damage of the injection pump cylinder No. 1 for the rotational speed of 750 rpm - result of modelling

Slika 17. Spektar ubrzanja vibracija na cilindru br. 1 motora 6 AL 20/24 koji radi s oštećenjem pumpe za ubrizgavanje na cilindru br. 1 na 750 okretaja - rezultat modeliranja

Table 1 Comparison of the values of vibration accelerations measured and simulated for the vertical direction V - cylinder No. 1 Tablica 1. Usporedba vrijednosti ubrzanja vibracija izmjerenih i simuliranih za vertikalni pravac $V$ - cilindar br. 1

\begin{tabular}{|c|c|c|c|c|c|}
\hline & $\begin{array}{c}\text { I harmonic } \\
\mathrm{a}\left[\mathrm{m} / \mathrm{s}^{2}\right]\end{array}$ & $\begin{array}{c}\text { II harmonic } \\
\mathrm{a}\left[\mathrm{m} / \mathrm{s}^{2}\right]\end{array}$ & $\begin{array}{c}\text { III harmonic } \\
\mathrm{a}\left[\mathrm{m} / \mathrm{s}^{2}\right]\end{array}$ & $\begin{array}{c}\text { VI harmonic } \\
\mathrm{a}\left[\mathrm{m} / \mathrm{s}^{2}\right]\end{array}$ \\
\hline Measured - efficient engine & 0.09 & 0.11 & 0.36 & 0.29 \\
\hline Simulated - efficient engine & 0.46 & 0.9 & 1.12 & 0.78 \\
\hline Measured - injection pump malfunction cyl. 1 . & 0.08 & 0.08 & 0.23 & 0.26 \\
\hline Simulated - injection pump malfunction cyl. 1 & 0.33 & 0.11 & 1.09 & 0.72 \\
\hline
\end{tabular}

Table 1 presents the results obtained from measurements and modelling one of the tested engine cylinders. The results achieved for the other cylinders show the same tendency. Analysis of collected data recorded during operation of the $6 A L$ 20/24 engine with simulated failure of the injection pumps allowed to state that in the case of failure to the injection pump of a given cylinder, consisting in reducing the amount of fuel supplied to the combustion chamber, the vibroactivity of this cylinder is reduced. The same dependencies were obtained by modelling. The developed model requires further tuning to achieve greater adequacy.

\section{CONCLUSIONS / Zaključci}

The research results presented in the paper confirm that there is a strong relationship between the technical condition of marine medium and high speed marine diesel engines injection pumps and vibration parameters recorded on the tightening bolts of engine heads. In addition, it is possible to indicate diagnostically sensitive parameters with simulations. The use of only vibration diagnostics limits the possibility of full identification of changes in the technical condition of injection system. Obtained results will be used to develop the proposed diagnostic method through the use of multi-symptom diagnostics methods. This step will enable identification of the original symptoms of changes in the technical condition of the fuel injection system in a non-invasive manner in the field of all rotational speeds and operational loads of marine diesel engines.

\section{REFERENCES / Literatura}

[1] Burdzik, R., Pankiewicz, J., Wạdołowski, M. (2016). "Analysis of bendingtorsional vibrations for diagnostics of the crank system". Diagnostyka, Vol. 17 No. 4, pp. 79-84.

[2] Iskra, A. (1995). Dynamics of crnak-piston mechanisms of internal combustion engines. Poznan: Poznan University of Technology. [in polish]

[3] Kluczyk, M. (2014). "An analysis of the kinematics and dynamics of a shaftpiston system in a single cylinder four-stroke engine ZS". Scientific Journal of Polish Naval Academy, Vol. 55, No. 3 (198), pp. 51-62.

[4] Kluczyk, M., Grządziela, A. (2017).“"High and medium speed marine diesel engines injection installation vibration diagnostic". Diagnostyka, Vol. 18, No. 2, pp. 37-42.

[5] Komorska, I. (2009). "Modeling of Vibration Signal for Reciprocating Engine Diagnostics". Diagnostyka, No. 2 (50), pp. 23-26.

[6] Lus, T., Łutowicz, M. (2010). "Marine diesel engines diagnostics". Research papers of Lithuanian University of Agriculture, Vol. 42, No. 2-3, pp. 141-149.

[7] Mihanović, L., Komar, I., Gržan, M. (2016). "Methodology Analysis Using Exploitation Reliability with the use of the RTOP Main Diesel Engine". NAŠE MORE, Vol. 63, No. 2, pp. 48-55. DOI: 10.17818/NM/2016/2.2. https://doi. org/10.17818/NM/2016/2.2

[8] Mrzljak, V., Medica, V., Bukovac, O. (2016). "Simulation of a Two-Stroke Slow Speed Diesel Engine Using a Quasi-Dimensional Model". Transactions of FAMENA, Vol. 40, No. 2, pp. 35-44. https://doi.org/10.21278/TOF.40203

[9] Pankiewicz, J., Deuszkiewicz, P., Dziurdź, J., Zawisza, M. (2014). “Modeling of powertrain system dynamic behavior with torsional vibration damper". Advanced Materials Research, Vol. 1036, pp. 586-591. https://doi.org/10.4028/ www.scientific.net/AMR.1036.586

[10] Radica, G., Antonić, R., Račić, N. (2009). “Engine Working Cycle Analysis for Diagnostic and Optimisation Purposes". Brodogradnja, Vol. 60, No. 4, pp. 378-387.

[11] Zawisza, M. (2008). “Diagnosing mechanical damages not detected by the OBD system of diesel engines". Journal of Vibroengineering, Vol. 19, No. 3, pp. 1833-1844. https://doi.org/10.21595/jve.2016.18075 